\title{
Facilitation of cholinergic transmission by combined treatment of ondansetron with flumazenil after cortical cholinergic deafferentation
}

\author{
Francisco J. Gil-Bea, Jon Domínguez, Mónica García-Alloza, Beatriz Marcos, \\ Berta Lasheras, María J. Ramírez* \\ Department of Pharmacology, School of Medicine, University of Navarra, Irunlarrea 1, 31008 Pamplona, Spain
}

Received 23 September 2003; received in revised form 23 December 2003; accepted 19 March 2004

\begin{abstract}
We have studied the effects of concomitant blockade of 5- $\mathrm{HT}_{3}$ and $\mathrm{GABA}_{\mathrm{A}}$ receptors on acetylcholine (ACh) release in the frontal cortex of rats with a selective cholinergic lesion. Lesions were performed by microinjection of the cholinergic toxin 192 IgG-saporin into the nucleus basalis magnocellularis. Single treatment with either the 5-HT 3 receptor antagonist ondansetron, $0.1 \mu \mathrm{g} / \mathrm{kg}$, or the $\mathrm{GABA}_{\mathrm{A}}$ receptor benzodiazepine site antagonist flumazenil, $10 \mathrm{mg} / \mathrm{kg}$, did not affect ACh release. However, the combined ondansetron + flumazenil administration significantly increased ACh release to a similar extent as a depolarising stimulus with $\mathrm{K}^{+}, 100 \mathrm{mM}$, at both 7 and 30 days post-lesion. Cortical perfusion with the combined ondansetron + flumazenil treatment also increased $\left[{ }^{3} \mathrm{H}\right] \mathrm{ACh}$ efflux "in vitro" 30 days after lesion, suggesting that local events within the frontal cortex may participate in the interaction of ondansetron with GABAergic neurons, modulating ACh release in situations of cholinergic hypoactivity. No differences in the expression of $5-\mathrm{HT}_{3}$ and $\mathrm{GABA}_{\mathrm{A}}$ receptors in the frontal cortex were found after the cholinergic lesion. These results suggest that a combined ondansetron + flumazenil treatment would contribute to restoring a diminished cholinergic function and may provide a basis for using this treatment in the therapy of cognitive disorders associated with degeneration of the cholinergic system.
\end{abstract}

(C) 2004 Elsevier Ltd. All rights reserved.

Keywords: 5- $\mathrm{HT}_{3}$ receptors; $\mathrm{GABA}_{\mathrm{A}}$ receptors; 192 IgG-saporin; Alzheimer's disease; Nucleus basalis magnocellularis

\section{Introduction}

Disruption of basal forebrain cholinergic pathways and consequent cortical cholinergic denervation is one of the hallmarks of Alzheimer's disease (AD) and other neurodegenerative conditions such as Parkinson's disease, dementia with Lewy bodies or vascular dementia (Michaelis, 2003; Terry and Buccafusco, 2003). This cholinergic dysfunction in AD has been largely related to cognitive disturbances (Perry et al., 1999). The cholinergic hypothesis of memory has led to multiple studies attempting cholinergic replacement therapy in these neurodegenerative diseases, and nowadays, activation

\footnotetext{
* Corresponding author. Tel.: +34-948425600; fax: +34-948425649

E-mail address: mariaja@unav.es (M.J. Ramírez).
}

and restoration of cholinergic function remains a major objective in the development of pharmacological approaches towards the treatment of cognitive dysfunctions associated with aging and dementia (see review by Terry and Buccafusco, 2003).

There is a wide body of evidence to suggest that serotonin (5-HT) plays an important role in learning and memory processes (see review Buhot et al., 2000). Biochemical and anatomical studies have shown a functional interaction between serotonergic and cholinergic systems (Maura et al., 1992; Cassel and Jeltsch, 1995) and therefore, serotonergic receptors could modulate the activity of the cholinergic system to cooperate in the regulation of cognitive processes (Barnes et al., 1989; Cassel and Jeltsch, 1995). In particular, the involvement of $5-\mathrm{HT}_{3}$ receptors in learning and memory has been repeatedly suggested and $5-\mathrm{HT}_{3}$ receptor 
antagonists, such as ondansetron, have been described as potential cognitive enhancers in the treatment of dementia (Costall and Naylor, 1997; Meneses, 1998). In addition to the effects on cognition, $5-\mathrm{HT}_{3}$ receptor antagonists have also been shown to be useful in the treatment of non-cognitive disorders, such as anxiety (Ye et al., 2001), that occur frequently in AD. Moreover, $5-\mathrm{HT}_{3}$ receptors seem to be preserved in the illness (Barnes et al., 1990).

Previous studies from our group have shown that the $5-\mathrm{HT}_{3}$ receptor antagonist ondansetron produces an enhancement in ACh release in the rat cerebral cortex and this effect is potentiated by $\mathrm{GABA}_{\mathrm{A}}$ receptor antagonists, such as bicuculline and flumazenil, both "in vitro" and "in vivo" (Ramirez et al., 1996; Diez-Ariza et al., 1998, 2002). Moreover, when evaluated for effects on cognition, a full reversal of the learning impairment induced by scopolamine was found after the combined treatment with ondansetron and flumazenil (Diez-Ariza et al., 2003).

It is hypothesised here that concomitant blockade of $5-\mathrm{HT}_{3}$ and $\mathrm{GABA}_{\mathrm{A}}$ receptors will be effective in facilitating ACh release in situations of cholinergic hypoactivity. Therefore, in the present study, the ability of single or combined treatment with ondansetron and flumazenil to induce ACh release has been evaluated in rats with a selective cholinergic lesion. Possible mechanisms implicated in the releasing effect of these drugs have also been investigated.

\section{Materials and methods}

\subsection{Drugs}

The following compounds were used: ondansetron (Vita, Spain); flumazenil, neostigmine bromide, hemicholinium-3, acetylthiocholine iodide (Sigma, UK); [methyl- ${ }^{3} \mathrm{H}$ ]choline chloride $(86 \mathrm{Ci} / \mathrm{mmol}),\left[9-\right.$ methyl $\left.-{ }^{3} \mathrm{H}\right]$ BRL 43694 (81 Ci/mmol), (PerkinElmer, USA); 192 IgG Saporin (Chemicon International Inc., USA); [methylamine- ${ }^{3} \mathrm{H}$ ]muscimol $(7.4 \mathrm{Ci} / \mathrm{mmol})$, (Amersham Pharmacia, UK). Inorganic salts and other reagents were from Merck and Sigma.

Ondansetron was dissolved in saline and flumazenil was dissolved by adding $0.1 \%$ Tween- 80 and then adjusting the solution to its final volume with saline.

\subsection{Animal housing}

Male Wistar rats weighing 230-250 g were used. Animals were kept at constant room temperature $\left(21 \pm 1{ }^{\circ} \mathrm{C}\right)$ and relative humidity $(55 \pm 5 \%)$ with a 12-h light/dark cycle (dark from 8 p.m.) and ad libitum access to food and water. All the experiments were carried out in strict compliance with the recommendations of the EU (DOCE L 358/1 18/2/1986) for the care and use of laboratory animals.

At the beginning of the study rats were allocated randomly to one of the experimental groups constituted by controls, sham-operated rats and rats with 192 IgG-saporin lesions.

\subsection{Surgery}

All surgical procedures were conducted under aseptic conditions. Rats were anaesthetised with a mixture of ketamine (10 mg/kg, i.p.; Ketasol, Parke-Davis, USA) and xylazine $(0.3 \mathrm{mg} / \mathrm{kg}$, i.p.; Rompun, Bayer, Germany) and placed in a stereotaxic frame (Kopf, USA), with the incisor bar set $3.5 \mathrm{~mm}$ below the interaural line. one microlitre of the immunotoxin 192 IgG-Saporin $(0.067 \mu \mathrm{g} / \mu \mathrm{l} / \mathrm{hemisphere;} \mathrm{Torres} \mathrm{et} \mathrm{al.,} \mathrm{1994)} \mathrm{was}$ infused bilaterally into the nucleus basalis magnocellularis (NBM) of the basal forebrain at the following coordinates (from bregma): AP $-0.9 \mathrm{~mm}, \mathrm{ML} \pm$ $2.9 \mathrm{~mm}, \mathrm{DV}-6.5 \mathrm{~mm}$, according to the atlas of Paxinos and Watson (1982). Sham animals received equivalent amounts of saline.

Post-lesion survival times were established at 7 and 30 days.

\subsection{Verification of lesions}

To assess the extent of the lesion, different cholinergic markers were measured in the frontal cortex. Acetylcholinesterase (AChE) activity was measured in the frontal cortex according to the colorimetric method described by Wang et al. (1999). The high-affinity choline uptake (HACU) system was determined according to the radiometric method of Lapchak and Hefti (1991). Choline acetyltransferase (ChAT) activity assay was performed according to the method of Ricceri et al. (2002).

Results are expressed as percentage of controls.

\subsection{Acetylcholine release "in vivo"}

Microdialysis probes were implanted into the right frontal cortex at the following coordinates: AP $3.2 \mathrm{~mm}$, ML $0.5 \mathrm{~mm}, \mathrm{DV}-3.5 \mathrm{~mm}$. The dialysis probes, had a diameter of $250 \mu \mathrm{m}$ and an exposed dialysis membrane (Cuprophan, Applied Neuroscience, UK) of $3 \mathrm{~mm}$.

Dialysis experiments were conducted during daytime $24 \mathrm{~h}$ after probe implantation surgery. The probes were perfused at a constant flow rate of $1.0 \mu \mathrm{l} / \mathrm{min}$, using a microperfusion pump (CMA, Sweden), with cerebrospinal fluid containing (in $\mathrm{mM}$ ): $\mathrm{NaCl} 120, \mathrm{KCl} 1.4$, $\mathrm{CaCl}_{2}, 1.2, \mathrm{MgCl}_{2} 0.83$, and $\mathrm{NaHCO}_{3} 20$, in a potassium phosphate buffer (1.3 mM; pH 7.4). The acetylcholinesterase inhibitor neostigmine bromide $(1 \mu \mathrm{M})$ 
was added to the perfusion solution in order to prevent degradation of ACh. Dialysate was discarded during the first 120-min equilibration period and then collected every $15 \mathrm{~min}$. After collection of three baseline fractions, tested drugs were administered i.p. The doses of drugs used were selected according to previous experiments in non-lesioned animals (Diez-Ariza et al., 2002, 2003). In another set of experiments, animals were perfused with $\mathrm{KCl}(100 \mathrm{mM})$ through the dialysis probe. Animals were never used in more than one dialysis session. Following the dialysis experiments, the accurate placement of the probes was verified post-mortem by gross examination of coronal sections.

ACh content in the dialysis samples was determined using high-performance liquid chromatography (HPLC) with electrochemical detection as previously reported (Rosenblad and Nilsson, 1993). ACh content was calculated by comparing with a 1 pmol standard. The sensitivity limit (signal-to-noise ratio $>2$ ) was $50 \mathrm{fmol}$.

\subsection{Acetylcholine release "in vitro"}

Induced $\mathrm{K}^{+}$-evoked $\left[{ }^{3} \mathrm{H}\right] \mathrm{ACh}$ efflux was measured as previously described (Ramírez et al., 1996). In brief, after labelling the tissue with $\left[{ }^{3} \mathrm{H}\right]$ choline $(3 \mu \mathrm{l} / \mathrm{ml}, 81$ $\mathrm{Ci} / \mathrm{mmol})$, aliquots $(150 \mu \mathrm{l})$ of packed slices were added to each chamber of a Brandel Superfusion-1000 apparatus and superfused with Krebs-Ringer bicarbonate buffer containing the choline reuptake inhibitor hemicholinium-3 $(1 \mu \mathrm{M})$. Fractions were collected at 3-min intervals for a total of $60 \mathrm{~min}$. At $12 \mathrm{~min}$ (S1) and $45 \mathrm{~min}$ (S2) after equilibration, the slices were depolarised by changing the superfusion fluid for $6 \mathrm{~min}$ to a solution containing $20-\mathrm{mM} \mathrm{KCl}$. Ondansetron and/or flumazenil were added 15 min before S2. Tritium content was assayed by liquid scintillation spectroscopy. $\mathrm{S} 1$ and $\mathrm{S} 2$ were calculated as $\mathrm{K}^{+}$-stimulated tritium increase over basal efflux. Results were expressed as $\mathrm{S} 2 / \mathrm{S} 1$ ratio.

\subsection{Binding assays}

All the measurements were assayed in duplicate and the data was subjected to Scatchard analysis in order to determine receptor density $\left(B_{\max }\right)$ and dissociation constant $\left(K_{\mathrm{d}}\right)$. The amount of protein in each tissue was assessed according to the method of Bradford (1976).

\subsection{1. [9-methyl- $\left.{ }^{3} H\right] B R L 43694$ binding to $5-H T_{3}$ receptors}

Membranes were prepared according to the method of Nelson and Thomas (1989). BRL 43694 binding assays contained $20 \mu \mathrm{l}$ of [9-methyl- ${ }^{3} \mathrm{H}$ ]BRL 43694 (concentrations ranged from 0.1 to $3 \mathrm{nM}$ ) and $\mathrm{BRL}$
$(100 \mu \mathrm{M})$ to determine non-specific binding, $100 \mu \mathrm{l}$ of tissue preparation and $700 \mu \mathrm{l}$ of $50 \mathrm{mM}$ HEPES (pH 7.7) in 1-ml final volume. The assays were incubated for $10 \mathrm{~min}$ on ice and then rapidly filtered through Wathman GF/C glass fibre filters. Filters were measured by liquid scintillation spectroscopy.

\subsection{2. [methylamine $-{ }^{3} H$ ]muscimol binding to $G A B A_{A}$ receptors}

Membranes were prepared according to the method of Green et al. (1996). Muscimol binding assays contained $20 \mu \mathrm{l}$ of [methylamine- ${ }^{3} \mathrm{H}$ ] muscimol (concentrations ranged from 2.5 to $50 \mathrm{nM})$, GABA $(100 \mu \mathrm{M})$ to determine non-specific binding and $160 \mu \mathrm{l}$ of tissue preparation (dilution 1:50) in 200- $\mu 1$ final volume. The assay was incubated for $10 \mathrm{~min}$ on ice and then rapidly filtered through Whatman GF/B glass fibre filters. Filters were measured by liquid scintillation spectroscopy.

\subsection{Statistical analysis}

Normality was checked using Shapiro-Wilks's test $(p>0.05)$ prior to any other statistical analysis.

The effect of lesion on cholinergic markers (AChE, ChAT and HACU levels), binding parameters ( $B_{\max }$, $\left.K_{\mathrm{d}}\right)$ and $\left[{ }^{3} \mathrm{H}\right] \mathrm{ACh}$ release was analysed using one-way ANOVA followed by Tukey's tests. The same statistical analysis was used to compare control with sham (7 and 30 days) animals.

In microdialysis experiments, ACh content in each sample was presented as mean \pm S.E.M. percentage of the average baseline level calculated from the first three samples in each animal group. Baseline levels of $\mathrm{ACh}$ release were compared using one-way ANOVA followed by Tukey's test. The statistical analysis of the effect of $5-\mathrm{HT}_{3}$ antagonist ondansetron (treatment 1) and $\mathrm{GABA}_{\mathrm{A}}$ antagonist flumazenil (treatment 2) on ACh outflow was assessed using a two-way ANOVA (treatment $1 \times$ treatment 2 ) with time as the repeated measure, followed by Tukey's test.

Summed effects of treatment over the course of an experiment were measured by determining the area under the curve (AUC, GraphPad Prism v. 3.02). AUC values were compared using a one-way ANOVA followed by Fisher's test for comparisons between control and experimental groups.

\section{Results}

\subsection{Characterisation of the selective cholinergic lesion}

Injection of $192 \mathrm{IgG}$-saporin into the NBM caused an overall decrease in the activity of the cholinergic markers in the frontal cortex. As summarised in Table 1, at both 7 and 30 days after lesion, ChAT and 
Table 1

Effect of a cholinergic lesion in the NBM on cholinergic parameters in the rat frontal cortex

\begin{tabular}{lcccll}
\hline $\begin{array}{l}\text { Animal } \\
\text { group }\end{array}$ & \%ChAT & \%AChE & HACU $(\mathrm{dpm})$ & $\begin{array}{l}\text { Basal ACh release "in } \\
\text { vivo", (fmol/15 } \mu \text { l) }\end{array}$ & $\begin{array}{l}\text { Basal ACh release "in } \\
\text { vitro", (dpm) }\end{array}$ \\
\hline Control & $100.00 \pm 7.62$ & $102.61 \pm 1.57$ & $755.66 \pm 37.56$ & $464.15 \pm 24.76$ & $2443.08 \pm 115.49$ \\
SAPO 7 days & $50.96 \pm 4.40^{*}$ & $52.89 \pm 4.25^{* *}$ & $577.94 \pm 34.54^{*}$ & $304.35 \pm 15.69^{* *}$ & $1053.39 \pm 45.62^{* *}$ \\
SAPO 30 days & $54.99 \pm 3.93^{*}$ & $55.06 \pm 2.73^{* *}$ & $504.99 \pm 3.03^{*}$ & $313.38 \pm 16.29^{* *}$ & $1185.73 \pm 46.61^{* *}$ \\
\hline
\end{tabular}

SAPO, rats with a selective cholinergic lesion induced by injection of 192 IgG-saporin into the NBM. ChAT, cholinacetyltransferase; AChE, acetylcholinesterase; HACU, high-affinity choline uptake. Data shown as mean \pm S.E.M. Control value for ChAT activity was $159.54 \pm 26.94 \mathrm{nmol} \mathrm{ACh} / \mathrm{h} / \mathrm{g}$ tissue. Control value for $\mathrm{AChE}$ absorbance was $0.28 \pm 0.32$. Percentage was calculated in relation to control values.

No differences were found between sham animals at either 7 or 30 days post-lesion and non-lesioned animals, therefore, for illustrative purposes only, these values have been combined in one Control group.

${ }^{*} p<0.05$ vs. Control (ANOVA followed by Tukey's test); $n=15-30$ per group.

${ }^{* *} p<0.001$ vs. Control.

AChE levels were significantly reduced to approximately $50 \%$ of the control values (one-way ANOVA, $F_{(3,117)}=109.46, p<0.001 ; F_{(3,33)}=19.46, p<0.001$, respectively). Significant decreases in HACU values were also found (one-way ANOVA, $F_{(3,18)}=11.79$, $p<0.001)$. No statistical differences were found between control and sham groups in ChAT, AChE and HACU levels.

\subsection{ACh release "in vivo" from the frontal cortex of lesioned rats}

As shown in Table 1, rats with cholinergic lesion of NBM showed a significant decrease, at both 7 and 30 days post-lesion, in basal $\mathrm{ACh}$ efflux relative to control values (one-way ANOVA, $F_{(3,79)}=10.73, p<0.001$ ).

Seven days after a selective cholinergic lesion, the time course of $\mathrm{ACh}$ release after single or combined treatment with ondansetron and flumazenil is presented in Fig. 1 (top panel). Selective blockade of $5-\mathrm{HT}_{3}$ receptor after administration of ondansetron, $0.1 \mu \mathrm{g} / \mathrm{kg}$ i.p., did not affect the basal ACh outflow, although, a non-significant peak of $35 \%$ over baseline was observed. Similarly, systemic administration of a selective $\mathrm{GABA}_{\mathrm{A}}$ receptor antagonist, flumazenil, $10 \mathrm{mg} / \mathrm{kg}$, i.p., also failed to significantly increase $\mathrm{ACh}$ efflux. However, combined treatment with ondansetron and flumazenil significantly enhanced ACh release (two-way ANOVA, $\left.F_{(3,54)}=2.91, p<0.05\right)$. Moreover, cumulating the release over fractions revealed (one-way ANOVA; $\left.F_{(3,20)}=2.97, p=0.05\right)$ a significant effect of the combined treatment compared to single administrations $(2300.85 \pm 336.60, \quad 2355.02 \pm 625.23, \quad 3639.83 \pm$ $391.99 \mathrm{fmol} \mathrm{ACh} / 105 \mathrm{~min}$, for ondansetron, flumazenil and the combined treatment, respectively).

Similarly, at longer post-lesion times (30 days), single administration of ondansetron or flumazenil did not modify ACh outflow from the frontal cortex of lesioned rats 30 days after the cholinergic lesion. However, the combined treatment of ondansetron+-
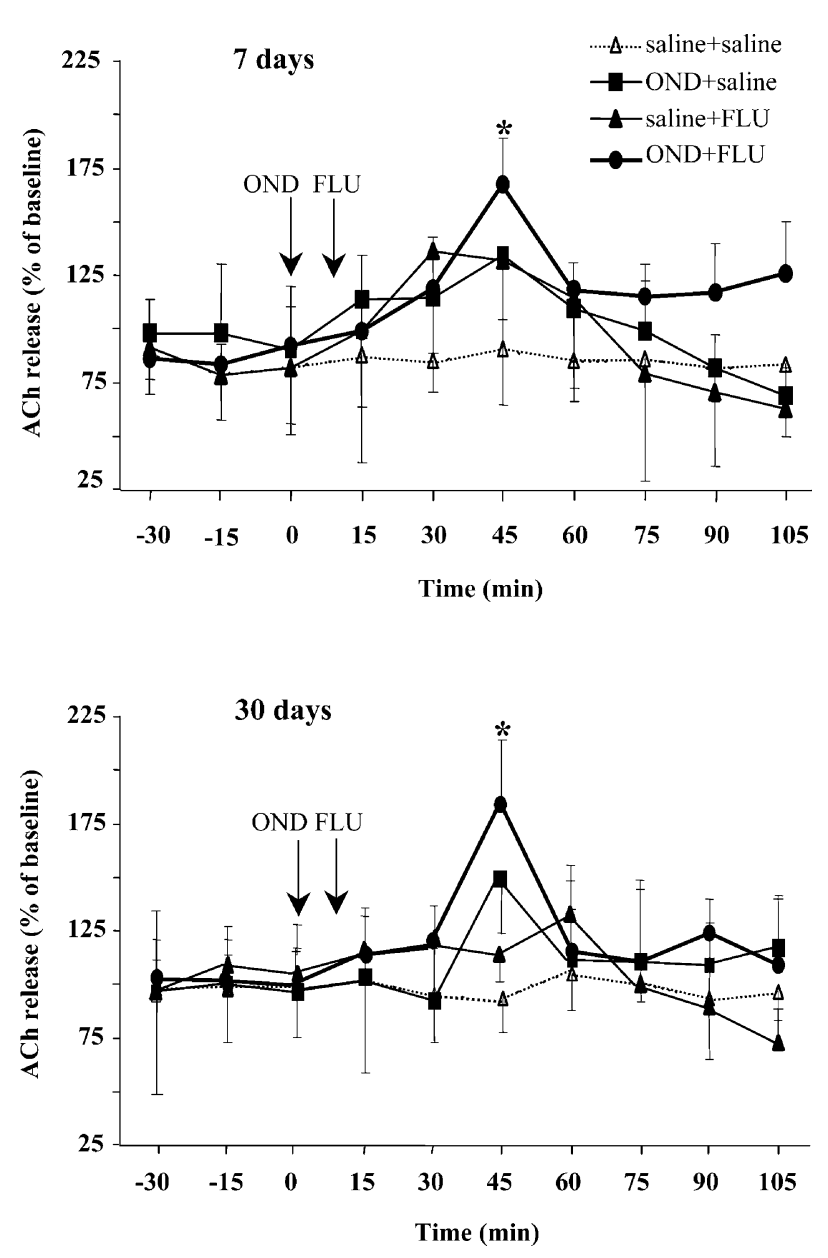

Fig. 1. Time-course of the ACh releasing effect of single or combined treatment with ondansetron and flumazenil in the frontal cortex of rats 7 (top panel) and 30 (bottom panel) days after a selective cholinergic lesion in the NBM. Basal levels of ACh were $304.35 \pm 15.69$ and $313.38 \pm 16.29 \mathrm{fmol} / 15 \mu \mathrm{l}$ in animals 7 and 30 days after the lesion, respectively. Data is mean \pm S.E.M. percentages of the baseline calculated from the overall three first basal samples ( $n=6-8$ per group). OND, ondansetron, $0.1 \mu \mathrm{g} / \mathrm{kg}$, i.p.; FLU, flumazenil, $10 \mathrm{mg} / \mathrm{kg}$, i.p. ${ }^{*} p<0.05$ or better vs. basal values (Two-way ANOVA followed by Tukey's test). 
flumazenil enhanced the peak releasing effect (two-way ANOVA, $F_{(3,45)}=3.66, p<0.01$; Fig. 1, bottom panel). Total ACh release, expressed as AUC, was also significantly higher (one-way ANOVA, $F_{(2,13)}=3.69, p=0.05$ ) after the combined treatment $(5292 \pm 1725 \mathrm{fmol}$ $\mathrm{ACh} / \mu \mathrm{l} / \mathrm{min})$ vs. single treatment with ondansetron $(1837 \pm 892 \mathrm{fmol} \mathrm{ACh} / \mu \mathrm{l} / \mathrm{min})$ or flumazenil $(1883 \pm$ $398 \mathrm{fmol} \mathrm{ACh} / \mu \mathrm{l} / \mathrm{min})$. Cumulating release over fractions in the combined treatment group was also significantly increased (one-way ANOVA; $F_{(3,23)}=3.86$, $p<0.05 ; \quad 1519 \pm 486, \quad 2220 \pm 225, \quad 3236 \pm 469 \mathrm{fmol}$ $\mathrm{ACh} / 105 \mathrm{~min}$, for ondansetron, flumazenil and the combined treatment, respectively).

Infusion through the dialysis probe of a local stimulus of $100 \mathrm{mM} \mathrm{KCl}$ during 30 min produced significant increases in $\mathrm{ACh}$ outflow over basal values in control and lesioned rats (Fig. 2), both at 7 (two-way ANOVA, $\left.F_{(3,54)}=7.64, p<0.01\right)$ and 30 days after a selective cholinergic lesion $\left(F_{(3,44)}=0.63, p<0.01\right)$. Peak increases in $\mathrm{ACh}$ release after the combined treatments were similar to those produced by a depolarizing stimulus with $\mathrm{KCl}$.

\subsection{Effect of ondansetron and flumazenil on $\mathrm{K}^{+}$-evoked $\left[{ }^{3} \mathrm{H}\right] \mathrm{ACh}$ release}

Basal $\left[{ }^{3} \mathrm{H}\right] \mathrm{ACh}$ release in lesioned rats was significantly diminished (Table 1) at both 7 and 30 days after the lesion (one-way ANOVA, $F_{(3,259)}=57.49$, $p<0.001)$.

Three different concentrations of ondansetron $(0.01$, 0.1 and $1 \mu \mathrm{M})$ and flumazenil $(1,10$ and $50 \mu \mathrm{M})$ were tested in their ability to release $\left[{ }^{3} \mathrm{H}\right] \mathrm{ACh}$ in lesioned animals.

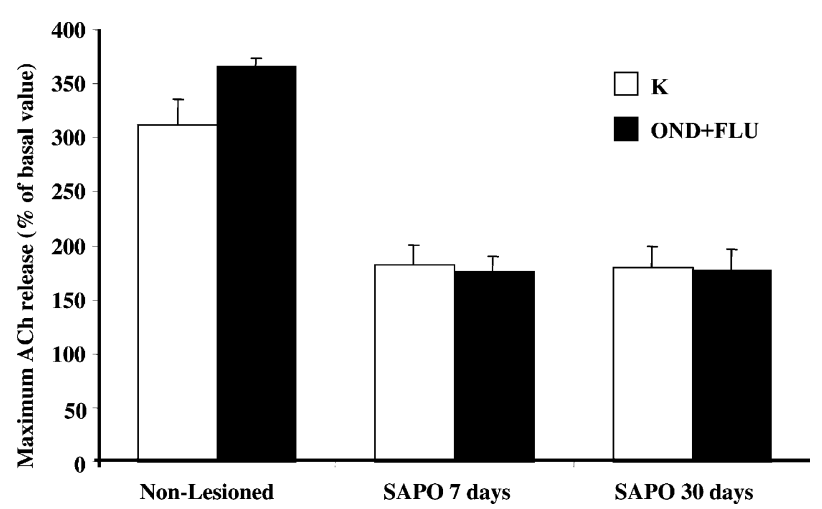

Fig. 2. Effects of $\mathrm{K}^{+}$and a combined administration of ondansetron and flumazenil on maximum cortical ACh release "in vivo" in non-lesioned control rats (as reported by Diez-Ariza et al., 2003) compared to rats with a selective cholinergic lesion (SAPO). Data is mean \pm S.E.M. percentages of the baseline calculated from the overall three first basal samples ( $n=6-8$ per group). $\mathrm{K}: \mathrm{K}^{+}, 100 \mathrm{mM}$; OND: ondansetron, $0.1 \mu \mathrm{g} / \mathrm{kg}$, i.p.; FLU: flumazenil, $10 \mathrm{mg} / \mathrm{kg}$, i.p. All increases were statistically significant vs. their correspondant basal values (Two-way ANOVA followed by Tukey's test).
Seven and 30 days after cholinergic lesion of NBM, none of the concentrations of ondansetron or flumazenil tested showed a significant intrinsic effect on the $\mathrm{K}^{+}$-evoked $\left[{ }^{3} \mathrm{H}\right] \mathrm{ACh}$ efflux from frontal cortex slices (data not shown), although some concentrations showed a trend towards an increased ACh release, e.g., flumazenil $\left(\begin{array}{ll}10 & \mu \mathrm{M}\end{array}\right)$ increased $\mathrm{S} 2 / \mathrm{S} 1$ ratio from $1.05 \pm 0.08$ (control) up to $1.30 \pm 0.14$ in 30 days lesioned animals. The concentrations of single treatments with ondansetron or flumazenil that yielded maximal, although non-significant $\left[{ }^{3} \mathrm{H}\right] \mathrm{ACh}$ release, were selected to check the effect of the combined treatment on "in vitro" ACh release.

The combined treatment with ondansetron $(0.1 \mu \mathrm{M})$ and flumazenil $(10 \mu \mathrm{M})$ yielded a non-significant increase in $\left[{ }^{3} \mathrm{H}\right] \mathrm{ACh}$ levels 7 days after the lesion. However, at the longer post-lesion time of 30 days, concomitant superfusion with ondansetron and flumazenil was able to significantly increase cortical ACh release in lesioned animals, and $\mathrm{S} 2 / \mathrm{S} 1$ ratio raised from $1.05 \pm 0.08$ (control) to $1.53 \pm 0.16$ (combined treatment with ondansetron and flumazenil, one-way ANOVA, $F_{(3,85)}=5.1, p<0.001$; Fig. 3).

\subsection{Effect of a selective cholinergic lesion on $\left[{ }^{3} H\right] B R L$ 43694 and $\left[^{3} \mathrm{H}\right]$ Muscimol binding in the rat frontal cortex}

As illustrated in Table 2, cholinergic lesion of the NBM did not show any effect on $\left[{ }^{3} \mathrm{H}\right] \mathrm{BRL} 43694$ binding in the frontal cortex (one-way ANOVA, ns).

Similarly, the selective cholinergic lesion of the NBM did not affect $\left[{ }^{3} \mathrm{H}\right]$ Muscimol binding in the frontal cortex either 7 or 30 days after lesion (one-way ANOVA, ns), although a non-significant $19 \%$ increase in $\mathrm{GABA}_{\mathrm{A}}$ receptor density, expressed as $B_{\text {max }}$, relative to controls, was found 7 days post-lesion.

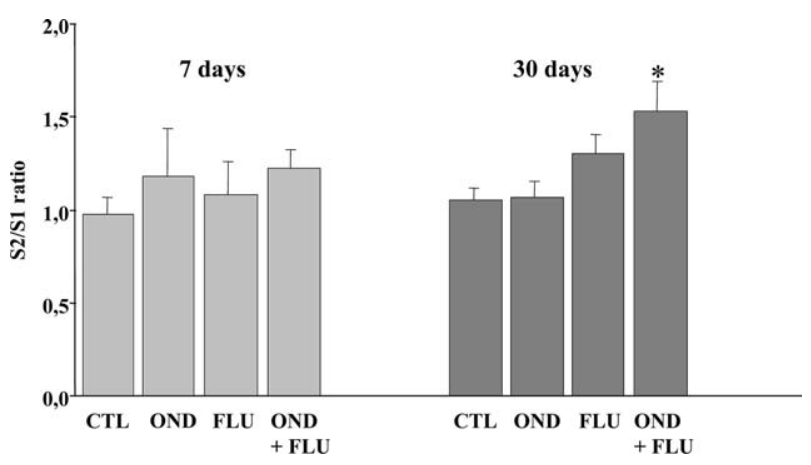

Fig. 3. Effect of single or combined administration of ondansetron and flumazenil on $\mathrm{K}^{+}$-evoked $\left[{ }^{3} \mathrm{H}\right] \mathrm{ACh}$ release in slices from frontal cortex of rats 7 and 30 days after a selective cholinergic lesion in the NBM. Values are presented as mean \pm S.E.M. $(n=12-14$ per group). CTL: control lesioned rats; OND: ondansetron, $0.1 \mu \mathrm{M}$; FLU: flumazenil, $10 \mu \mathrm{M} ;{ }^{*} p<0.05$ vs. control values (One-way ANOVA followed by Tukey's test). 
Table 2

Effect of a selective cholinergic lesion in the $\mathrm{NBM}$ on $5-\mathrm{HT}_{3}$ and $\mathrm{GABA}_{\mathrm{A}}$ receptor densities in the rat frontal cortex

\begin{tabular}{|c|c|c|c|c|}
\hline \multirow[t]{2}{*}{ Animal group } & \multicolumn{2}{|l|}{$\left[5-\mathrm{HT}_{3}\right]$} & \multicolumn{2}{|l|}{$\left[\mathrm{GABA}_{\mathrm{A}}\right]$} \\
\hline & $B_{\max }(\mathrm{fmol} / \mathrm{mg}$ protein $)$ & $K_{\mathrm{d}}(\mathrm{nM})$ & $B_{\max }(\mathrm{fmol} / \mathrm{mg}$ protein $)$ & $K_{\mathrm{d}}(\mathrm{nM})$ \\
\hline Control & $23.95 \pm 1.57$ & $1.83 \pm 0.24$ & $423.52 \pm 26.43$ & $7.69 \pm 0.46$ \\
\hline SAPO 7 days & $25.10 \pm 2.00$ & $2.29 \pm 0.29$ & $485.01 \pm 31.40$ & $7.39 \pm 1.22$ \\
\hline SAPO 30 days & $18.66 \pm 1.59$ & $2.18 \pm 0.70$ & $409.02 \pm 22.58$ & $9.99 \pm 1.07$ \\
\hline
\end{tabular}

SAPO, animals with a selective cholinergic lesion induced by injection of 192 IgG-saporin into the NBM. Data expressed as mean \pm S.E.M.; $n=6-11$ per group. No differences were found between sham animals at either 7 or 30 days post-lesion and non-lesioned animals, therefore, for illustrative purposes only, these values have been combined in one Control group.

\section{Discussion}

Previous neurochemical and behavioural studies from our group support the notion that concomitant blockade of $5-\mathrm{HT}_{3}$ and $\mathrm{GABA}_{\mathrm{A}}$ receptors enhances learning in animal models of cognitive dysfunction through an enhancement of cholinergic neurotransmission (Ramirez et al., 1996; Diez-Ariza et al., 1998, 2002, 2003). In the present work it was found that combined treatment with $5-\mathrm{HT}_{3}$ and $\mathrm{GABA}_{\mathrm{A}}$ receptor antagonists was able to significantly increase $\mathrm{ACh}$ release in situations of cholinergic hypoactivity.

Cholinergic neurons in the NBM give rise to a dense network of cholinergic fibres innervating the entire cortical mantle (Wainer and Mesulam, 1990). Partial cortical cholinergic deafferentiation was achieved by intraparenchymal infusion of the selective cholinergic immunotoxin, 192 IgG-Saporin, into the NBM (Heckers et al., 1994; Torres et al., 1994). The post-lesion time of 7 days was used in this study because it has been described that 7 days after lesion, cholinergic damage is entirely achieved (Fadel et al., 1996). The post-lesion time of 30 days was also selected to allow for the possible development of long-term compensatory mechanisms acting to restore ACh levels after cholinergic lesions (Cossette et al., 1993). Under our experimental conditions, a significant decrease in cholinergic function was achieved, as reflected by significant decreases in cholinergic markers in the frontal cortex of lesioned animals similar to those previously described after this type of lesion (Wenk et al., 1994; Rossner et al., 1995; Lacalle et al., 1998).

As expected (Fadel et al., 1996), a decrease in basal cortical ACh level was found at both post-lesion times. However, ACh release "in vivo" is reduced after the lesion to a lesser extent than ChAT or AChE activity. These findings suggest that surviving cholinergic neurons may up-regulate ACh turnover "in vivo" to compensate for cholinergic denervation. It has been described that following partial destruction of afferent cholinergic fibres that innervate different brain regions, such as the hippocampus, residual cholinergic neurons are able to up-regulate their capacity to synthesise and store ACh "in vivo" (Lapchak et al., 1991) or even that incomplete lesions of the NBM produced increases in basal ACh release (Mcgaughy et al., 2002). The question about the responsiveness of neurons surviving lesions to the combined treatment was addressed next. The doses of drugs used were selected according to our previous studies, in which the combined treatment with ondansetron, $0.1 \mu \mathrm{g} / \mathrm{kg}$, and flumazenil, $10 \mathrm{mg} / \mathrm{kg}$, showed a maximal effect on cortical ACh release "in vivo" (Diez-Ariza et al., 2002) and was able to reverse scopolamine-induced learning (Diez-Ariza et al., 2003). Interestingly, and at both 7 and 30 days after lesion, concomitant administration of ondansetron with flumazenil significantly increased ACh release (expressed as maximum release, cumulated release or AUC) even though single treatment with either drug was ineffective. As might be expected, the increase in ACh release after the combined treatment in lesioned animals was lower than in control animals (Diez-Ariza et al., 2002). However, it should be noted that the releasing effect of the combined treatment was similar to the effect of a high depolarizing stimulus, such as $\mathrm{KCl}(100 \mathrm{mM})$, known to produce a maximal $\mathrm{ACh}$ release both in young or aged rats (Herzog et al., 2003) or after a cholinergic lesion (Rosenblad and Nilsson, 1993).

When considering the mechanisms responsible for the effects of the combined ondansetron + flumazenil treatment, it is possible to speculate that there is a blockade of the inhibitory influence of GABA neurons by ondansetron. GABA-type neurons in the basal forebrain have been found to be directly excited by $5-\mathrm{HT}$ (Alreja, 1996) and the co-existence of 5- $\mathrm{HT}_{3}$ transcripts with GABA immunoreactivity in several areas of the telencephalon, including the basal forebrain, has also been reported (Morales and Bloom, 1997). This blockade might be produced on the soma of neurons originating from the NBM, but also on local intrinsic mechanisms within the cortex.

In an attempt to elucidate the contribution of local cortical mechanisms to the releasing effect of the treatment with ondansetron + flumazenil, ACh release induced by these drugs was studied "in vitro" in cortical slices from lesioned animals. The concentrations of ondansetron and flumazenil that produced maximal, although non-significant $\mathrm{ACh}$ release, were similar to 
those used in previous studies in non-lesioned animals (Diez-Ariza et al., 1998). A significant enhancement of ACh release after the combined treatment was found only at the post-lesion time of 30 days. In light of these observations it is possible to speculate that at short post-lesion times, the contribution of local events to the releasing effect is minimal. However, at longer postlesion times, local compensatory mechanisms could be responsible for the significant effect on ACh release after ondansetron + flumazenil treatment. In relation to this idea, behavioural studies have hypothesised that, in situations of cholinergic hypoactivity, the serotonergic system could be involved in local mechanisms to compensate for the loss of cholinergic innervation (RichterLevin and Segal, 1996; Harkany et al., 2000).

It is even possible to speculate about a regulation in the expression of $5-\mathrm{HT}_{3}$ and $\mathrm{GABA}_{\mathrm{A}}$ receptors as part of these compensatory mechanisms. However, cholinergic lesions failed to alter the density of these receptors, suggesting that $5-\mathrm{HT}_{3}$ and $\mathrm{GABA}_{\mathrm{A}}$ receptors are located in neurons, either extrinsically or intrinsically to the cortex, that survive the lesions (Eckenstein et al., 1988). Only a non-significant $15-20 \%$ increase in $\mathrm{GABA}_{\mathrm{A}}$ receptor density in the frontal cortex was observed at 7 days post-lesion. Similar increases were found after a non-selective cholinergic lesion with ibotenic acid (Rossner et al., 1995) or intracerebroventricular infusion of 192 IgG-Saporin (Rossner et al., 1994).

Following the cholinergic hypothesis of dementia, it is possible to suggest that the combined treatment of ondansetron + flumazenil should be evaluated using a cognition test in animals with selective cholinergic lesions. However, even tough selective cholinergic damage has been described after 192 IgG-saporin lesions, only modest deficits in mnemonic tasks have been reported (Torres et al., 1994; Baxter et al., 1996; Power et al., 2002). It has been speculated that cognitive mechanisms are mediated via cortical $\mathrm{ACh}$, pointing to a role for this neurotransmitter system in the processing of behaviourally relevant sensory information e.g. attention and arousal. It has also been hypothesised that cortical ACh modulates the general efficacy of the cortical processing of sensory or associational information. Regardless of the mechanism, cholinergic replacement therapy nowadays remains the major strategy for the treatment of cognitive dysfunctions in AD (Michaelis, 2003; Terry and Buccafusco, 2003).

In conclusion, the present results show that the combined treatment with ondansetron and flumazenil is capable of significantly enhancing ACh release in situations of cholinergic hypoactivity, such as the initial phases of $\mathrm{AD}$. Drugs such as $5-\mathrm{HT}_{3}$ receptor antagonists, which are devoid of severe adverse side effects (Goodin and Cunningham, 2002), may provide a more effective treatment strategy, particularly in the elderly, than compounds acting directly on cholinergic trans- mission, which have proved to be disappointing as therapeutic agents, because of problematic side effects, narrow effective dose ranges and short duration of action (Inglis, 2002). Taken together, the present results might be of particular interest in the treatment of neurodegenerative diseases associated with a cholinergic dysfunction.

\section{Acknowledgements}

This work has been supported by a grant from Gobierno de Navarra (Spain). F.J. Gil-Bea has a scholarship form Gobierno de Navarra (Spain). M. Garcia-Alloza has a BEFI scholarship from ISCIII (Spain, expte 00/9479). The authors thank M.L. Muro and S. Lizaso for technical help.

\section{References}

Alreja, M., 1996. Excitatory actions of serotonin on GABAergic neurons of the medial septum and diagonal band of Broca. Synapse 22, 15-27.

Barnes, J.M., Barnes, N.M., Costall, B., Naylor, R.J., Tyers, M.B., 1989. $5-\mathrm{HT}_{3}$ receptors mediate inhibition of acetylcholine release in cortical tissue. Nature 338, 762-763.

Barnes, J.M., Barnes, N.M., Costall, B., Deakin, J.F., Ironside, J.W., Kilpatrick, G.J., Naylor, R.J., Rudd, J.A., Simpson, M.D., Slater, P., et al., 1990. Identification and distribution of 5-HT3 recognition sites within the human brainstem. Neurosci. Lett. 111, $80-86$.

Baxter, M.G., Bucci, D.J., Sobel, T.J., Williams, M.J., Gorman, L.K., Gallagher, M., 1996. Intact spatial learning following lesions of basal forebrain cholinergic neurons. Neuroreport 7, $1417-1420$.

Bradford, M.M., 1976. A rapid and sensitive method for the quantification of microgram quantities of protein utilizing the principle of protein-dye binding. Annal. Biochem. 72, 248-254.

Buhot, M.C., Martin, S., Segu, L., 2000. Role of serotonin in memory impairment. Ann. Med. 32, 210-221.

Cassel, J.C., Jeltsch, H., 1995. Serotonergic modulation of cholinergic function in the central nervous system: cognitive implications. Neuroscience 69, 1-41.

Cossette, P., Umbriaco, D., Zamar, N., Hamel, E., Descarries, L., 1993. Recovery of choline acetyltransferase activity without sprouting of the residual acetylcholine innervation in adult rat cerebral cortex after lesion of the nucleus basalis. Brain Res. 630, 195-206.

Costall, B., Naylor, R.J., 1997. Neuropharmacology of 5-HT3 receptors ligands. In: Baumgarten, H.G., Göthert, M. (Eds.), Serotonergic Neurons and 5-HTR Receptors in the CNS. Springer-Verlag, Berlin, pp. 408-436.

Diez-Ariza, M., Ramirez, M.J., Lasheras, B., Del Rio, J., 1998. Differential interactions between $5-\mathrm{HT}_{3}$ receptors and GABAergic neurons inhibiting acetylcholine release in rat entorhinal cortex slices. Brain Res. 801, 228-232.

Diez-Ariza, M., Garcia-Alloza, M., Lasheras, B., Del Rio, J., Ramirez, M.J., 2002. GABA $A_{A}$ receptor antagonists enhance cortical acetylcholine release induced by $5-\mathrm{HT}_{3}$ receptor blockade in freely moving rats. Brain Res. 956, 81-85.

Diez-Ariza, M., Redondo, C., García-Alloza, M., Lasheras, L., Del Río, J., Ramírez, M.J., 2003. Flumazenil and tacrine increase the effective- 
ness of ondansetron on scopolamine-induced impairment of spatial learning in rats. Psychopharmacology (Berl) 169, 35-41.

Eckenstein, F.P., Baughman, R.W., Quinn, J., 1988. An anatomical study of cholinergic innervation in rat cerebral cortex. Neuroscience 25, 457-474.

Fadel, J., Moore, H., Sarter, M., Bruno, J.P., 1996. Trans-synaptic stimulation of cortical acetylcholine release after partial 192 IgGsaporin-induced loss of cortical cholinergic afferents. J. Neurosci. $16,6592-6600$

Green, A.R., Misra, A., Murray, T.K., Snape, M.F., Cross, A.J., 1996. A behavioural and neurochemical study in rats of the pharmacology of loreclezole, a novel allosteric modulator of the $\mathrm{GABA}_{\mathrm{A}}$ receptor. Neuropharmacology $35,1243-1250$.

Goodin, S., Cunningham, R., 2002. 5-HT3-receptor antagonists for the treatment of nausea and vomiting: a reappraisal of their sideeffect profile. Oncologist 7, 424-436.

Harkany, T., Dijkstra, I.M., Oosterink, B.J., Horvath, K.M., Abraham, I., Keijser, J., Van der Zee, E.A., Luiten, P.G., 2000. Increased amyloid precursor protein expression and serotonergic sprouting following excitotoxic lesion of the rat magnocellular nucleus basalis: neuroprotection by $\mathrm{Ca}^{2+}$ antagonist nimodipine. Neuroscience 101, 101-114.

Heckers, S., Ohtake, T., Wiley, R.G., Lappi, D.A., Geula, C., Mesulam, M.M., 1994. Complete selective cholinergic denervation of rat neocortex and hippocampus but not amygdala by an immunotoxin against the p75 NGF receptor. J. Neurosci. 14, 1271-1289.

Herzog, C.D., Nowak, K.A., Sarter, M., Bruno, J.P., 2003. Microdialysis without acetylcholinesterase inhibition reveals an agerelated attenuation in stimulated cortical acetylcholine release. Neurobiol. Aging 24, 861-863.

Inglis, F., 2002. The tolerability and safety of cholinesterase inhibitors in the treatment of dementia. Int. J. Clin. Pract. Suppl. 127, 45-63.

Lacalle, S., Kukarni, S., Wiley, R.G., 1998. Lesion-induced transneuronal plasticity of the cholinergic innervation in the adult entorhinal cortex. Eur. J. Neurosci. 10, 1054-1062.

Lapchak, P.A., Hefti, F., 1991. Effect of recombinant human nerve growth factor on presynaptic cholinergic function in rat hippocampal slices following partial septohippocampal lesions: measures of $[3 \mathrm{H}]$ acetylcholine synthesis, $[3 \mathrm{H}]$ acetylcholine release and choline acetyltransferase activity. Neuroscience 42, 639-649.

Lapchak, P.A., Jenden, D.J., Hefti, F., 1991. Compensatory elevation of acetylcholine in vivo by cholinergic neurons surviving partial lesions of the septohippocampal pathway. J. Neurosci. 9, 2821-2828.

Maura, G., Andioli, G.C., Cavazzani, R., Raiteri, M., 1992. 5Hidroxytryptamine $_{3}$ receptors sited on cholinergic axon terminals of human cerebral cortex mediate inhibition of acetylcholine release. J. Neurochem. 58, 2334-2337.

Mcgaughy, J., Dalley, J.W., Morrison, C.H., Everitt, B.J., Robbins, T.W., 2002. Selective behavioral and neurochemical effects of cholinergic lesions produced by intrabasalis infusions of 192 IgGSaporin on attentional performance in a five-choice serial reaction time task. J. Neurosci. 22, 1905-1913.

Meneses, A., 1998. Physiological, pathophysiological and therapeutic roles of 5-HT system in learning and memory. Rev. Neurosci. 9, 275-289.

Michaelis, M.L., 2003. Drugs targeting Alzheimer's disease: some things old and some things new. J. Pharmacol. Exp. Ther. 304, 897-904.
Morales, M., Bloom, F.E., 1997. The 5- $\mathrm{HT}_{3}$ receptor is present in different subpopulations of GABAergic neurons in the rat telencephalon. J. Neurosci. 17, 3157-3167.

Nelson, D.R., Thomas, D.R., 1989. [ $\left.{ }^{3} \mathrm{H}\right]-$ BRL 43694 (Granisetron), a specific ligand for $5-\mathrm{HT}_{3}$ binding sites in rat brain cortical membranes. Biochem. Pharmacol. 38, 1693-1695.

Paxinos, G., Watson, C., 1982. The Rat Brain in Stereotaxic Coordinates. Academic Press, San Diego.

Perry, E.K., Walker, M., Grace, J., Perry, R., 1999. Acetylcholine in mind: a neurotransmitter correlate fo consciousness? TINS 22, 273-280.

Power, A.E., Thal, L.J., Mcgaugh, J.L., 2002. Lesions of the nucleus basalis magnocellularis induced by 192 IgG-saporin block memory enhancement with posttraining norepinephrine in the basolateral amygdala. Proc. Natl. Acad Sci. USA 99, 2315-2319.

Ramirez, M.J., Cenarruzabeitia, E., Lasheras, B., Del Rio, J., 1996. Involvement of GABA systems in acetylcholine release induced by 5 - $\mathrm{HT}_{3}$ receptor blockade in slices from rat entorhinal cortex. Brain Res. 712, 274-280.

Ricceri, L., Hohmann, C., Berger-Sweeney, J., 2002. Early neonatal 192 IgG-Saporin induces learning impairments and disrupts cortical morphogenesis in rats. Brain Res. 954, 160-172.

Richter-Levin, G., Segal, M., 1996. Serotonin, aging and cognitive functions of the hippocampus. Rev. Neurosci. 7, 103-113.

Rosenblad, C., Nilsson, O.G., 1993. Basal forebrain grafts in the rat neocortex restore in vivo acetylcholine release and respond to behavioural activation. Neuroscience 55, 353-362.

Rossner, S., Schliebs, R., Bigl, V., 1994. Ibotenic acid lesion of nucleus basalis magnocellularis differentially affects cholinergic, glutamatergic and GABAergic markers in cortical rat brain regions. Brain Res. 668, 85-99.

Rossner, S., Schliebs, R., Perez-Polo, J.R., Wiley, R.G., Bigl, V., 1995. Differential changes in cholinergic markers from selected brain regions after specific immunolesion of the rat cholinergic basal forebrain system. J. Neurosci. Res. 40, 31-43.

Terry, A.V., Buccafusco, J.J., 2003. The cholinergic hypothesis of age and Alzheimer's disease-related cognitive deficits: recent challenges and their implications for novel drug development. J. Pharmacol. Exp. Ther. 306, 821-827.

Torres, E.M., Perry, T.A., Blockland, A., Wilkinson, L.S., Wiley, R.G., Lappi, D.A., Dunnet, S.B., 1994. Behavioural, histochemical and biochemical consequences of selective immunolesions in discrete regions of the basal forebrain cholinergic system. Neuroscience 63, 95-122.

Wainer, B.H., Mesulam, M.M., 1990. Ascending cholinergic pathways in the rat brain. In: Steriade, M., Biesold, D. (Eds.), Brain Cholinergic Systems. Oxford University Press, Oxford, pp. 65-119.

Wang, H., Carlier, P.R., Ho, W.L., Wu, D.C., Lee, N.T., Li, C.P.L., Pang, Y.P., Han, Y.F., 1999. Effects of bis(7)-tacrine, a novel anti-Alzheimer's agent, on rat brain AChE. Neuroreport 10, 789-793.

Wenk, G.L., Stoehr, J.D., Quintana, G., Mobley, S., Wiley, R.G., 1994. Behavioural, biochemical, histological and electrophysiological effects of $192 \mathrm{IgG}$-saporin injections into the basal forebrain of rats. J. Neurosci. 14, 285-290.

Ye, J.H., Ponnudurai, R., Schaefer, R., 2001. Ondansetron: a selective $5-\mathrm{HT}_{3}$ receptor antagonist and its applications in CNSrelated disorders. CNS Drug Rev. 7, 199-213. 